\title{
Effect of Hyper and Hypothyroidism on Lipid Profile and Liver Function of Male Rats
}

\author{
Ferial A. Al-Manaf Al-Mahdawi * Abeer Uthman Moosa*
}

Received 15, July, 2008

Accepted 3, January, 2011

\section{Abstract:}

This study was designed to investigate the effect of thyroid hormone disturbance on lipids profiles and liver functions.

Eighteen mature male rats Rattus norvegicus were divided into three groups. The first and the second groups were injected subcutaneously with thyroxine $\left(\mathrm{T}_{4}\right)$ and carbimazol (both at $600 \mu \mathrm{g} / \mathrm{kg} \mathrm{BW}$ ) respectively on alternate days, to produce recurrent periods of hyper and hypothyroidism .The control group which is the third group was injected with physiological saline. The process continued 4 weeks, after that, injection, blood specimens were collected to estimate serum levels of T3 and T4, Total cholesterol (TC), Triglycerides (TG), High density lipoprotein cholesterol (HDL-C), Low density lipoprotein cholesterol (LDL-C) and Very low density lipoprotein cholesterol (VLDL-C) were determined in the serum. In addition to that, we measure GOT, GPT and CPK enzymes activity.

The results showed no significant difference in body weight and a significant increase $(\mathrm{P}<0.01)$ in liver weight of Thyroxine injected group, while Carbimazol injected group showed significant increase $(\mathrm{P}<0.05)$ in body and in liver weight.

There was a significant decrease in TC concentration and there was no significant decrease in TG, HDL-C, LDL-C and VLDL-C concentration in the serum of Thyroxine injected group, while the Carbimazol injected group showed significant increase in serum TC, LDL-C, TG, HDL-C and VLDL-C concentration.

The results also pointed to a significant increase in GOT and GPT activity, and no significant decrease in CPK activity in the serum of thyroxine injected group, in addition to a significant increase in GPT activity and a significant increase in GOT activity without any significant differences in CPK activity noticed in the liver homogenate of the same group. The results also pointed to a significant increase in GOT and GPT activity, and significant increase in CPK activity in the serum of Carbimazol injected group, with significant decrease in GOT activity, significant decrease in GPT activity and significant increase in CPK activity in the liver homogenate of the same group.

Results of the liver histological study showed changes in the liver histological structure in both groups. An increasing in T3 and T4 levels led to a little expansion in the sinusoids and this might be due to accumulation of glycoprotein, also there was a centrilobular hepatocytes necrosis and congestion with RBCs in the sinusoids of central area due to hypoxia especially in perivenular hepatocytes area. In addition to extravasations of RBCs between the hepatocytes which are severely atrophied and some are necrosed.

It was noticed that there is a direct relationship between low levels of T4 and T3 and the hepatic dysfunction which led to sinusoids expansion, granular and hydropic degeneration due to hepatocytes immunological or toxically damaged which gave the hepatocytes edema appearance.

Key words: Hypothyroidism, Hyperthyroidism, Lipid profiles

*Biology Dept. / College of Science / University of Baghdad 


\section{Introduction:}

Thyroid gland is one of the most important endocrine glands found in the body. It plays an important role in maintaining body metabolism and effects on central nervous system, anterior pituitary gland, circulation and regulates all the physiological activities of different organs and tissues such as the heart and liver [1].

Thyroid hormone has both direct and indirect actions on the cardiovascular system [2]. The heart is a main target organ for thyroid hormone action, and marked changes occur in cardiac function in patients with hypo- or hyperthyroidism [3]. Thyroid hormones have significant effects on the synthesis, mobilization and metabolism of lipids, so any disturbance in Thyroid hormones leads to dyslipidemia [4]. Elevated in the levels of TC, LDL-C, and TG in case of hypothyroidism increase the risk of cardiovascular disease such as coronary artery diseases and atherosclerosis [5].While in case of hyperthyroidism, decreasing in the levels of TC, LDL-C, and TG, and stimulating the oxidation of LDL-C will lead to increase the risk of heart disease [6].

The studies have shown that there is a relationship between thyroid gland and the liver [7]. Thyroid hormones have an important rule in maintaining the natural liver function and bilirubin metabolism, so there is a relationship between the thyroid diseases and liver disorders [8].

The aim of this study was to determine how the thyroid hormones' disturbance may leads to lipid level disorders which considered as a risk factor of coronary artery diseases and also may produce alteration in liver functions.

\section{Materials and Methods:}

Eighteen Five-months-old rats Rattus norvegicus, weighing 115-125 g, were housed under a controlled lighting schedule (14-h light/10-h dark), and fed commercial diet and water ad libitum. were used in this study. They were divided in to 3 equal groups. The first one was injected with $600 \mu \mathrm{g} / \mathrm{Kg}$ of Thyroxine to induce a hyperthyroidism state, and the second one was injected with $600 \mu \mathrm{g} / \mathrm{Kg}$ of Carbimazol to induce a hypothyroidism state, While the third one was treated with normal physiological saline $(0.9 \% \mathrm{NaCl})$. Following 4 weeks of injecting on alternate days, the animals' weight was measured and blood was collected by cardiac puncture by using syringe ( 5 $\mathrm{ml}$ capacity). Then it centrifuged (5000 rpm for $15 \mathrm{~min}$.) which to obtain the serum in freezer under -20 until it used to measure the $T_{3}, T_{4}$ levels by using Radioimmuno Assay (RIA) [9] and.TC, TG, HDL-C, LDL-C, VLDL$\mathrm{C}$ levels and GOT, GPT, CPK activity by using spectrophotometer $[10$, 11].Then rats were killed by cervical dislocation and the liver was excised under sterile conditions and $2 \mathrm{gm}$ of it was homogenized to determine GOT, GPT, and CPK activity.

\section{Results and Discussion: 1-Effect of Thyroxine and Carbimazol in T3 and T4 levels of rats:}

The results showed significant increase $(\mathrm{P}<0.01)$ in serum level of $\mathrm{T} 3$ and $\mathrm{T} 4$ in the Thyroxine injected group and significant decrease $(\mathrm{P}<0.01)$ in serum level of T3 and T4 in the Carbimazol injected group (table-1). Carbimazol may close the T3 and T4 production pathways [12], or due to reduce binding rate of $\mathrm{T} 3$ and $\mathrm{T} 4$ with the carrier proteins such as TBPA and TBG. [13]. 


\section{2-Effect of Thyroxine and} Carbimazol in body and liver weight of rats:

The results showed (table-1) no significant decrease $(\mathrm{P}>0.05)$ in body weight and a significant increase $(\mathrm{P}<0.01)$ in liver weight of Thyroxine injected group, while the Carbimazol injected group showed significant increasein the body and liver weight. This is because of the maximal lipolytic response and sensitivity to catecholamines were increase in adipocytes [14]. while the increase in liver weight of both rats injected with T4 and carbimazol was explained by the recent research which used triiodothyronine as a hepatic growth factor and showed that T3 might be a primary mitogen for the liver in animal models (i.e. it induces hepatocyte proliferation and increases liver mass when administered at high doses in the absence of hepatic injury) [15].

\section{3-Effect of Thyroxine and \\ Carbimazol on Lipids levels in the serum:}

Rats injected with T4 showed decreasing in TC, TG, and Lipoproteins (HDL-C, LDL-C, and VLDL-C) concentration due to the rapid clearing of chylomicron remnants from blood stimulating cholesteryl ester transfer which in turn stimulate lipoprotein lipase., while the Carbimazol injected group showed significant increase in TC and LDL-C concentration (table-2), and significant increase in TG, HDL-C and VLDL-C concentration. The primary mechanism for hypercholesterolemia in Rats injected with carbimazol is accumulation of LDL $-\mathrm{C}$ due to a reduction in the number of cell surface receptors for LDL, resulting in decrease catabolism of LDL and diminished secretion of cholesterol in to bile and reduced cholesteryl ester transfer and reduced lipoprotein lipase is responsible for the development of hypertriglyceridemia $[10,16]$.

\section{4-Effect of Thyroxine and Carbimazol in GOT, GPT, CPK activity:}

The results also pointed to significant increase $(\mathrm{P}<0.01)$ in GOT and GPT enzyme activity, and no significant decrease in CPK activity in the serum of Thyroxine injected group, in addition to a significant increase $(\mathrm{P}<0.01) \quad$ in GPT activity and significant increase in GOT activity without any significant differences in CPK activity noticed in the liver homogenate of the same group. The results also pointed to a significant increase $(\mathrm{P}<0.05)$ in GOT and GPT activity, and significant increase $(\mathrm{P}<0.01)$ in $\mathrm{CPK}$ activity in the serum of Carbimazol injected group, while a significant decrease $(\mathrm{P}<0.01)$ in GOT activity, significant decrease $(\mathrm{P}<0.05)$ in GPT activity and significant increase $(\mathrm{P}<0.01)$ in $\mathrm{CPK}$ activity noticed in the liver homogenate of the same group (table-3).

An elevation in the GOT and GPT activity in serum of rats injected with thyroxine may be due to metabolism increasing in hepatocytes which lead in turn to increase GOT \& GPT [7], or due to the damage which may happen in the hepatocytes leading to leakage of enzymes from the cells [17]. As well as, the increasing of GOT, GPT and CPK activity in serum of rats injected with carbimazol due to increase in rates of enzymes leakage from the hepatocytes and reduce enzymes clearance from blood. [11, 18].

while the increase in GOT \& GPT activity in the liver homogenate of rats injected with $\mathrm{T} 4$ might be resulted from the breaking down of hepatocytes' membranes due to homogenizing process which led to enzyme releasing from the cells [19]. 
Inversely the decreasing of GOT, GPT and CPK activity in the liver homogenate of rats injected with carbimazol might be increased from increased rates of enzymes leakage from the cells to the blood due to membrane permeability [17].

Table (1) The changes in T3 and T4 hormones and body and liver weights of rats injected with $600 \mu \mathrm{g} \backslash \mathrm{Kg}$ of thyroxin and $600 \mu \mathrm{g} \backslash \mathrm{Kg}$ carbimazol.

\begin{tabular}{|c|c|c|c|c|c|}
\hline \multirow[b]{2}{*}{ Measurements } & \multirow[b]{2}{*}{$\mathrm{T}_{4} \mathrm{~nm} / \mathrm{L}$} & \multirow[b]{2}{*}{$\mathbf{T}_{3} \mathbf{n m} / \mathbf{L}$} & \multicolumn{2}{|c|}{ Body weight gm } & \multirow{2}{*}{$\begin{array}{c}\text { Liver weight gm/100gm } \\
\text { of body weight }\end{array}$} \\
\hline & & & $\begin{array}{c}\text { before } \\
\text { injection }\end{array}$ & $\begin{array}{c}\text { after } \\
\text { injection }\end{array}$ & \\
\hline Control & $96 \pm 3.93$ & $\begin{array}{c}1.29 \pm \\
0.09\end{array}$ & $\begin{array}{c}115.5 \pm \\
10.32\end{array}$ & $\begin{array}{c}127.9 \\
\pm 20.50\end{array}$ & $3.42 \pm 0.27$ \\
\hline $\begin{array}{c}\text { Rats injected with } \\
\text { Thyroxin }\end{array}$ & $\begin{array}{c}* * 114.38 \pm \\
5.37 \\
\end{array}$ & $\begin{array}{c}* * 2.8 \pm \\
0.09\end{array}$ & $\begin{array}{c}123.81 \pm \\
0.83\end{array}$ & $\begin{array}{c}125.78 \pm \\
1.41\end{array}$ & $* * 4.67 \pm 0.82$ \\
\hline $\begin{array}{l}\text { Rats injected with } \\
\text { Carbimazol }\end{array}$ & $\begin{array}{c}* * 80.36 \pm \\
6.85\end{array}$ & $\begin{array}{c}* * 0.85 \pm \\
0.03\end{array}$ & $\begin{array}{c}125.98 \pm \\
1.30\end{array}$ & $\begin{array}{c}141.3 \pm \\
1.11\end{array}$ & $* 4.55 \pm 0.63$ \\
\hline
\end{tabular}

Values represented Mean \pm SD (Standard Deviation)

*Significant differences $(\mathbf{P}<\mathbf{0 . 0 5}) \quad * *$ Significant differences $(\mathbf{P}<0.01)$

Table (2) The changes in lipids levels in rats injected with $600 \mu \mathrm{g} / \mathrm{Kg}$ of thyroxin and $600 \mu \mathrm{g} \backslash \mathrm{Kg}$ carbimazol.

\begin{tabular}{|c|c|c|c|c|c|}
\hline Measurements & $\begin{array}{c}\text { Total Cholesterol } \\
\mathbf{m g} / \mathbf{d L}\end{array}$ & $\begin{array}{c}\text { Triglyceride } \\
\mathbf{m g} / \mathbf{d L}\end{array}$ & $\begin{array}{c}\text { HDL-C } \\
\mathbf{m g} / \mathbf{d L}\end{array}$ & $\begin{array}{c}\text { LDL-C } \\
\mathbf{m g} / \mathbf{d L}\end{array}$ & $\begin{array}{c}\text { VLDL-C } \\
\mathbf{m g} / \mathbf{d L}\end{array}$ \\
\hline Control & $61.26 \pm 3.34$ & $39.11 \pm 3.21$ & $\begin{array}{c}11.91 \pm \\
1.35\end{array}$ & $41.4 \pm 5.04$ & $7.82 \pm 0.63$ \\
\hline $\begin{array}{c}\text { Rats injected } \\
\text { with } \\
\text { Thyroxin }\end{array}$ & $* 48.63 \pm 3.86$ & $33.67 \pm 1.50$ & $9.62 \pm 1.70$ & $\begin{array}{c}35.08 \pm \\
4.41\end{array}$ & $6.73 \pm 0.18$ \\
\hline $\begin{array}{c}\text { Rats injected } \\
\text { with } \\
\text { Carbimazol }\end{array}$ & $* * 83.87 \pm 1.33$ & $* 47.49 \pm 5.69$ & $* 16.85 \pm$ & $* * 57.01 \pm$ & $* 9.40 \pm$ \\
0.54 & 5.20 & 1.09 \\
\hline
\end{tabular}

Values represented Mean \pm SD (Standard Deviation)

*Significant differences $(P<0.05) \quad * *$ Significant differences $(P<0.01)$

Table (3) The changes in serum and liver homogenate enzymes activity in rats injected with $600 \mu \mathrm{g} / \mathrm{Kg}$ of thyroxine and $600 \mu \mathrm{g} \backslash \mathrm{Kg}$ carbimazol.

\begin{tabular}{|c|c|c|c|c|c|c|}
\hline & \multicolumn{2}{|c|}{ GOT unit/L } & \multicolumn{2}{|c|}{ GPT unit/L } & \multicolumn{2}{|c|}{ CPK unit/L } \\
\hline & Serum & $\begin{array}{c}\text { Liver } \\
\text { Homogenate }\end{array}$ & Serum & $\begin{array}{c}\text { Liver } \\
\text { Homogenate }\end{array}$ & Serum & $\begin{array}{c}\text { Liver } \\
\text { Homogenate }\end{array}$ \\
\hline Control & $14.62 \pm 1.51$ & $332.60 \pm 4.27$ & $8.42 \pm 1.67$ & $108.42 \pm 5.89$ & $77.56 \pm 3.02$ & $214.66 \pm 16.38$ \\
\hline $\begin{array}{c}\text { Rats } \\
\text { injected } \\
\text { with } \\
\text { Thyroxin }\end{array}$ & $\begin{array}{c}* * \\
120.5 \pm 19.70\end{array}$ & $\begin{array}{c}* 358.21 \\
42.52\end{array}$ & $\begin{array}{c}* * 26 \pm \\
7.17\end{array}$ & $* * 141.3 \pm 13.5$ & $72.40 \pm 1.62$ & $236.60 \pm 25.14$ \\
\hline $\begin{array}{c}\text { Rats } \\
\text { injected } \\
\text { with } \\
\text { Carbimazol }\end{array}$ & $* 33.25 \pm 3.26$ & $* * 110.6 \pm 3.46$ & $\begin{array}{c}* 15.52 \pm \\
2.06\end{array}$ & $* 63.4 \pm 6.82$ & $\begin{array}{c}* * 119.85 \pm \\
9.19\end{array}$ & $* * 718 \pm 46.30$ \\
\hline
\end{tabular}

Values represented Mean \pm SD (Standard Deviation)

*Significant differences $(\mathbf{P}<0.05) \quad * *$ Significant differences $(\mathbf{P}<0.01)$

\section{5-Histological changes:}

An increasing in $\mathrm{T} 3$ and $\mathrm{T} 4$ levels led to a little expansion in the sinusoids and this might be due to accumulation of glycoprotein, Fig. (1), also there was a centrilobular hepatocytes necrosis and congestion with RBCs in the sinusoids of central area due to hypoxia especially in perivenular hepatocytes area, Fig. (2) [8]. In addition to extravasations of RBCs between the hepatocytes which are severely atrophied and some are necrosed Fig. (3) comparing with control Fig. (4). 
The results also showed an increasing $(\mathrm{P}<0.01)$ in hepatocytes diameter mean might be explained by the Recent work investigating the use of triiodothyronine as a hepatic growth factor has shown it to be a primary mitogen for the liver in animal models (i.e. it induces hepatocyte proliferation and increases liver mass when administered at high doses in the absence of hepatic injury) [15] Fig. (5). It was noticed that there is a directly relationship between low levels of T4 and T3 and the hepatic dysfunction [20] which led to sinusoids expansion and bloody congestion Fig.(6) granular and hydropic degeneration due to hepatocytes immunological or toxically damaged which gave the hepatocytes edema appearance [21] Fig. (7).

An increasing in hepatocytes diameter mean rats injected with carbimazol might be due to glycogen accumulation in hepatocytes [22].

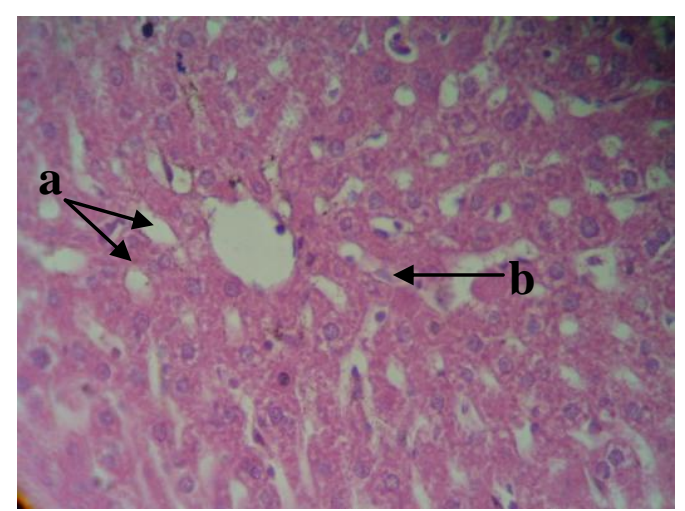

Fig. (1) Section in liver of rats injected with $600 \mu \mathrm{g} / \mathrm{Kg}$ of carbimazol showing: a-sinusoids expanse, b-hyperplasia of kuffer cells. . (H\&E) stain (10X).

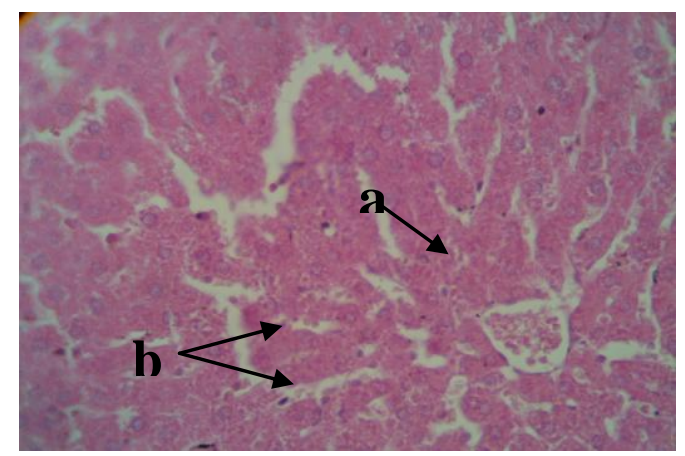

Fig. (2) : Section in liver of rats injected with $600 \mu \mathrm{g} / \mathrm{Kg}$ of thyroxine showing: a-centrilobular hepatocytes necrosis, b-sinusoids engorged with RBCs.

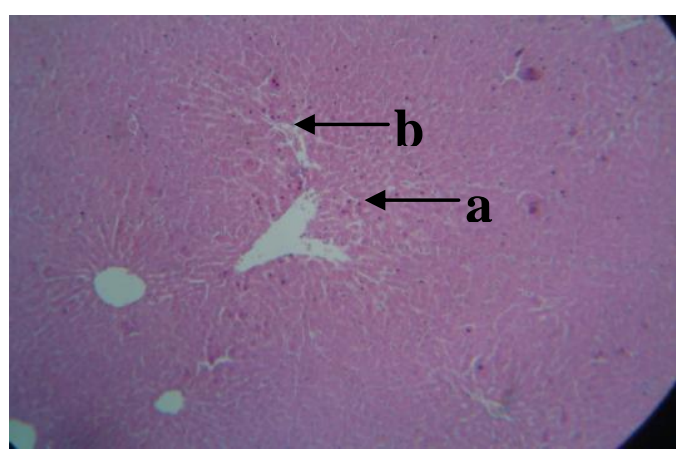

Fig. (3): Section in liver of rats injected with $600 \mu \mathrm{gg} / \mathrm{Kg}$ of thyroxine showing: a- cloudy degeneration, b- venous congestion.

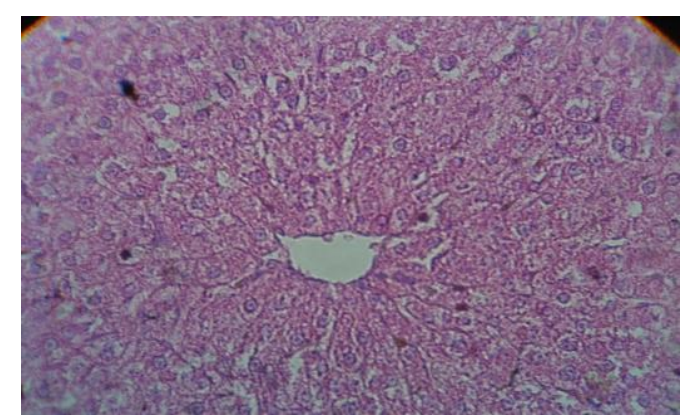

Fig. (4) : Section in control liver lobule consists of normal hepatocytes, arranged in cords with the sinusoids in between around the central vein. 


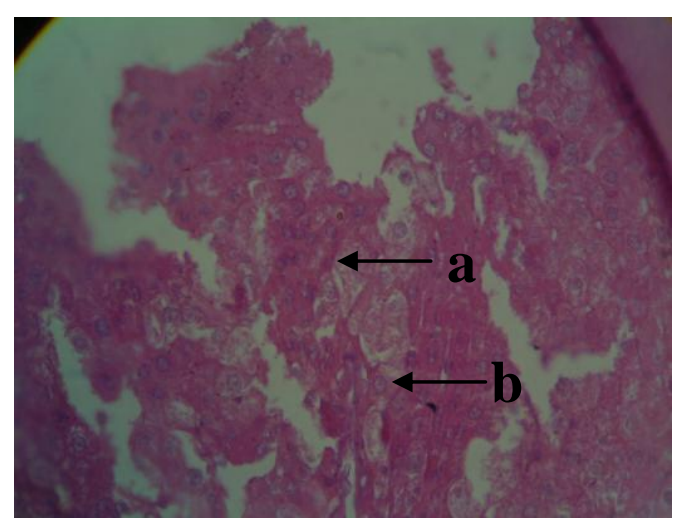

Fig. (5) : Section in liver of rats injected with $600 \mu \mathrm{g} / \mathrm{Kg}$ of thyroxine showing: a- hydropic degeneration of some hepatocytes, b-.others show signs of congestion and atrophy.

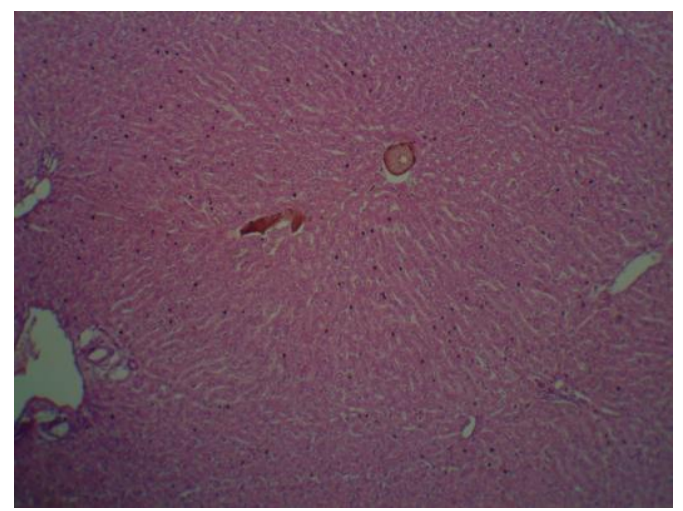

Fig. (6) Section in liver of rats injected with $600 \mu \mathrm{g} / \mathrm{Kg}$ of carbimazol showing: sinusoids expanse and bloody congestion. (H\&E) stain (10X)

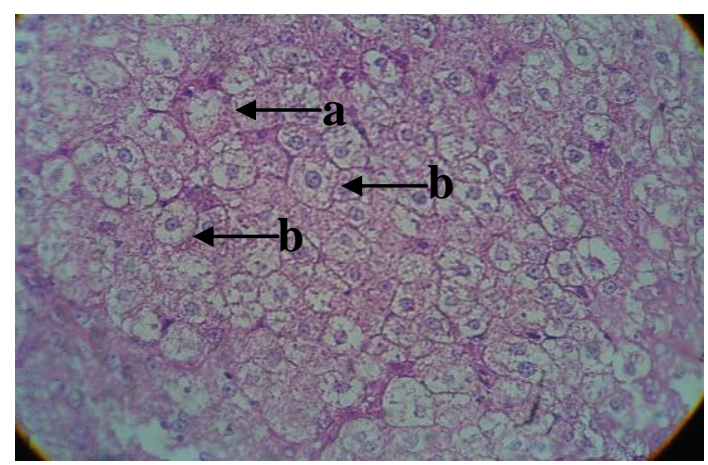

Fig. (7): Section in liver of rats injected with $600 \mu \mathrm{gg} / \mathrm{Kg}$ of carbimazol showing: a-marked hydropic degeneration, b-prominent of cells \& nuclei membranes.

\section{References:}

1. Ganong, W.F.2003. Review of Medical Physiology. McGraw Hill Companies; Inc. $21^{\text {th }}$ ed. Pp 296-311.

2. Klein, I. and Ojamaa K. 2001. Thyroid Hormone and the Cardiovascular System. NEJM. 344(7):501-509.

3. Kahaly,G.J. and Dillmann W.H. 2005. Thyroid Hormone Action in The Heart. Endo. Rev. 26(5):704728 .

4. Walsh, J. P.; Bremner, A. P.; Bulsara, M. K. ; O'Leary P.; Leedman, P. J.; Feddema, P. and Michelangeli,V. 2005. Thyroid dysfunction and serum lipids: a community-based study. Clin. Endocrinol.63 (3):670-675.

5. Cappola, A.R. and Ladenson P.W. 2003. Hypothyroidism and Atherosclerosis. J. Clin. Endo. \& Met. 88(6): 2438-2444.

6. Reaven, P.D. and Witzum J.L. 1995. The Role of Oxidation of LDL in Atherogenesis. Endocrinologist. 5:44-54.

7. Malik, R; Mellor N.; Selden C. and Hodgson H. 2000. Characterizing the Effects of Thyroid Hormone on the Liver. Gut. 34 (1):77-78.

8. Huang, M.J. and Liaw Y.F. 1995. Clinical Associations between Thyroid and Liver Diseases. J.Gastroenterol. Hepatol., 10(3): 344-350.

9. Manna, P.R.; Kero J.; TenaSempere M.; Pakarinen P.; Stocco D. M. and Huhtaniemi I. T. 2001. Assessment of Mechanisms of Thyroid Hormone Action in Mouse Leydig Cells: Regulation of the Steroidogenic Acute Regulatory Protein, Steroidogenesis, and Luteinizing Hormone Receptor Function. Endocrinology. 142 (1): 319-331. 
10. Ross, D.S. 1999. Lipid Abnormalities in Thyroid Disease.Thyroid.6:155-156.

11. Saha, B. and Maity C. _2002. Alteration of Serum Enzymes in Primary Hypothyroidism. Clin. Chem. Lab Med. 40(6):609-611.

12. Woeber, K.A.2000. Up Date on the Management of Hyperthyroidism and Hypothyroidism. Arch. Fam.Med. 9:743-747.

13. Pruett, H.E.; Thompson D.L.; Cartmill J.A.; Williams C.C. and Gentry L.R. 2003. Thyrotropin Releasing Hormone Interaction with Growth Hormone Secretion in Horse's. J.Anim.Sci, 81(9):23432351.

14. Germack,R.; Starzec A. and Perret G.Y. . 2000. Regulation of $\boldsymbol{\beta}_{1^{-}}$ and $\boldsymbol{\beta}_{3 \text {-adrenergic }}$ agoniststimulated lipolytic response in hyperthyroid and hypothyroid rat white adipocytes. Brit. J. Pharm. 129: 448-456.

15. Malik, R. and Hodgson H. 2002. The Relationship between The Thyroid Gland and The Liver.QJ Med 95(9):559-569.

16. Langer, P; Kocan A.; TajTakova M.; and et al.2003. Thyroid Function and Cholesterol Level: Paradoxical Findings in Large Groups of Population with High Cholesterol Food Intake. Endo. Reg.3:175-180.
17. Khan,M.; Coovadia X.M,; Karvas J.A.; Connolly C.. And Sturm A.W. 1999. Clinical Significance of Hepatic Dysfunction With Jaundice in Thyroid- Fever. Dig. Dis. and Sci. 44:590-591.

18. Dahlstedt, A. J.; Wieringa, A. B. and Hakanwesterbiad 2000. Is creatine kinase responsiple for fatigue? studies of isolated skeletal muscle deficient in creatine kinase. FASEB J.14:982990.

19. Burnett, J.R.; Crooke M.J.; Delahunt J.W. and Feek C.M. 1994. Serum Enzymes in Hypothyroidism. NZ Med J.14:355-356.

20. Novis, M.; Vaisman M. and Coelho H.S. 2002. Positive Relationship between the Low Serum Levels of T3 and Elevated Serum Levels of rT3 and IrT3/T3 with the Degree of Hepatic Dysfunction. Hbv Res. arch. 8(54):24-25.

21. Kumar,V; Cortan R. and Robbins S. 2003. Robbins Basic Pathology. $7^{\text {th }}$ ed, saunders. An imprint of Elsevier. Pp 592-607.

22. Al-Habeeb, O. A. 1991. The Animal Physiology. Dar Al- Kutub for printing and reported. AlMosel. Pp 413-417. 


\section{تأثير فرطوقصور الدرقية في الدهون ووظائف الكبد في ذكور الجرذان}

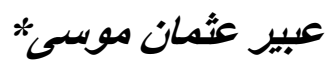

فريال عبد المناف المهذ/وي*

* قسم علوم الحياة / كلية العلوم / جامعة بغداد

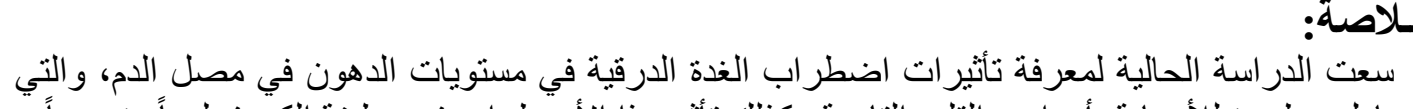

تعد عامل خطورة للأصابة بأمر اض القلب التاجية وكذلك تأثنير هذا الأضطر اب التئ في وظيفة الكبد فسلجياً ونسيجياً.

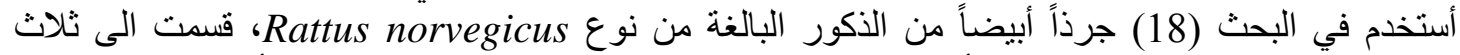

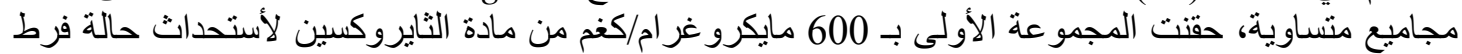

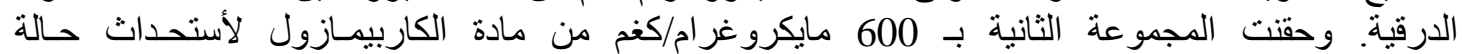

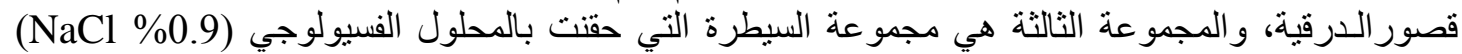

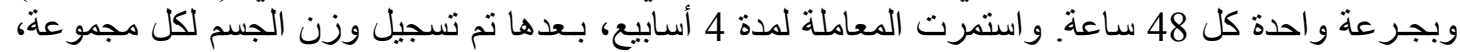

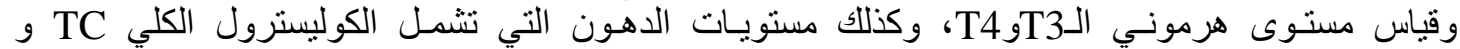
الكليسيريدات الثثلاثية TG وكوليسترول البروتين الدهني عالي الكثافة و اطيء الكثافة LDL-C وكوليسترول البروتين الدهني و اطيء الكئنافة جداً

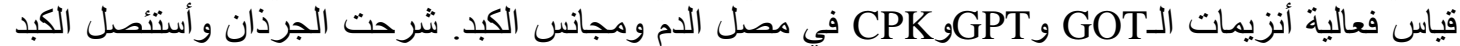

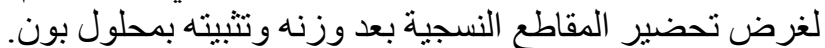

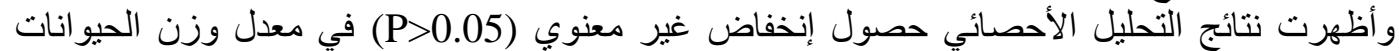

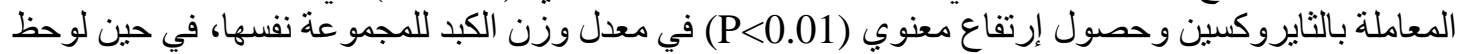

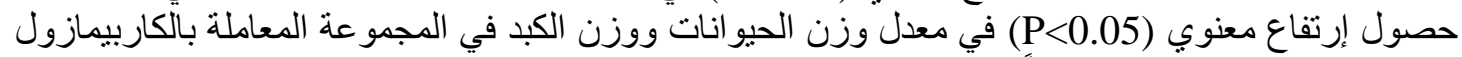

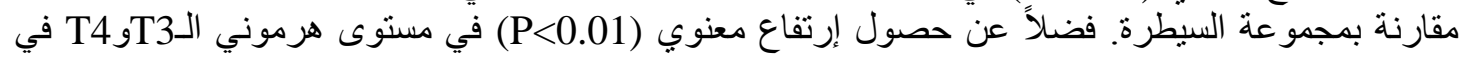

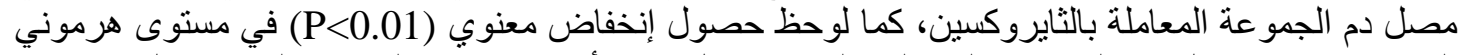

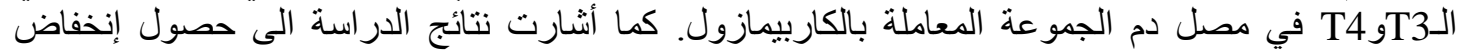

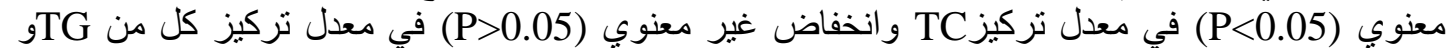

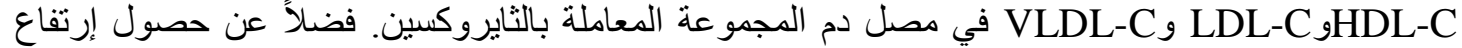
معنوي (P<0.01) في معدل تركيز PDL-C و وحصول إرتفاع معنوي (P<0.05) أيضا في معدل تركيز

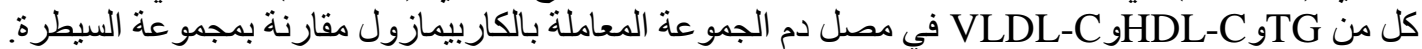

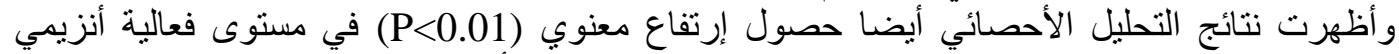

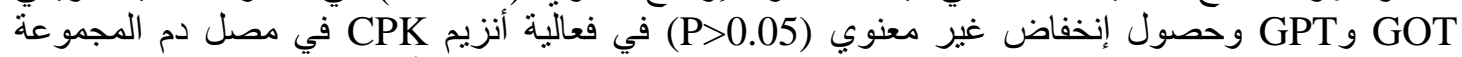

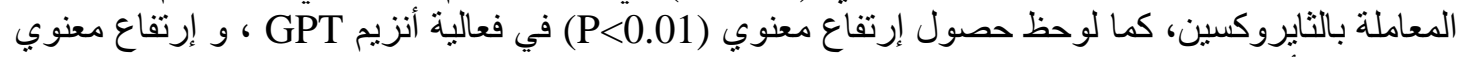
أيضا في فعالية الـ GOT (P<0.05)

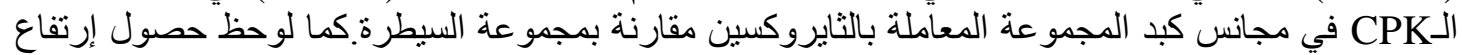

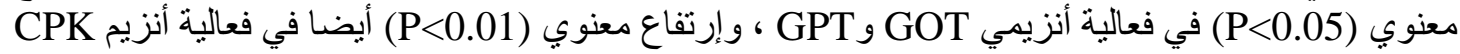

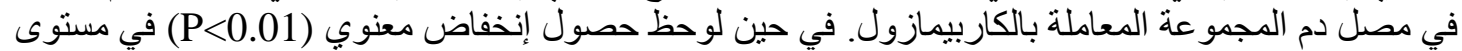

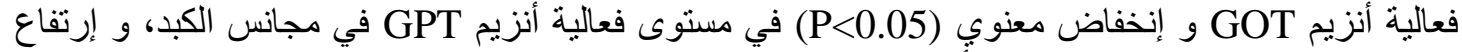

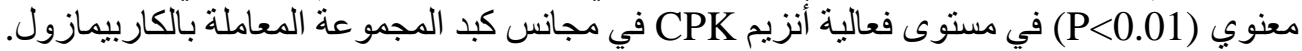

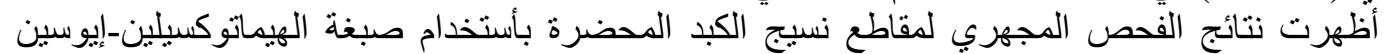

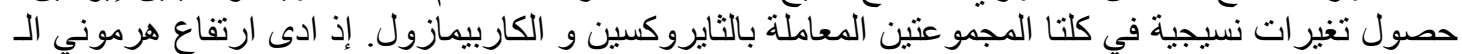

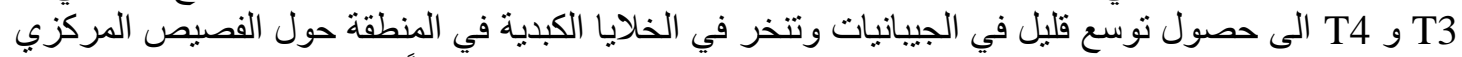

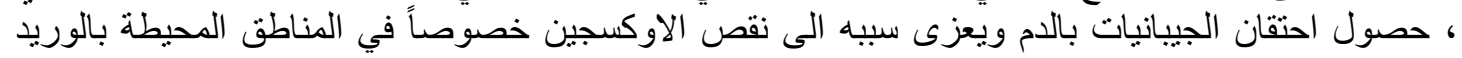

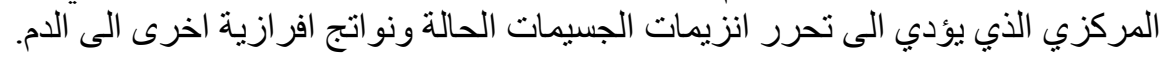

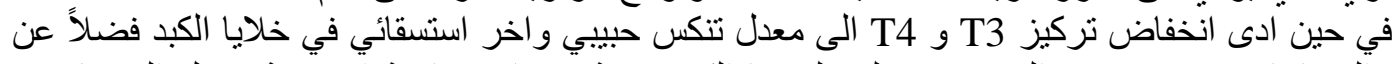
توسع الجيبانيات ويعزى سببه الى حدوث تلف لخيل لخلايا الكبد نتيجة لاسباب مناعية أو سمية يجعل الخلايا تبدو بمظهر وذمي منتفخ. 